\title{
PENDIDIKAN ISLAM KONTEMPORER PERSPEKTIF HASAN LANGGULUNG DAN ZAKIAH DARAJAT
}

\author{
Muhamad Basyrul Muvid \\ Universitas Dinamika Surabaya \\ Email: muvid@dinamika.ac.id \\ $\underline{\text { Miftahuuddin }}$ \\ Universitas Islam Negeri Sunan Kalijaga Yogyakarta \\ Email: miftahaddakhil@gmail.com
}

Moh. Abdullah

STAI Miftahul Ulum Pamekasan

Email: aabsaen661@gmail.com

\begin{abstract}
Abstrak
Artikel ini bertujuan untuk menganalisis pemikiran pendidikan Islam kontemporer Hasan Langgulung dan Zakiah Darajat yang kemudian dicari titik temu antar keduanya. Pendidikan Islam harus senantiasa update dan berbenah di tengah arus global yang begitu cepat, agar bisa selalu eksis dalam menjawab berbagai tantangan dan kebutuhan global. Metode yang digunakan dalam artikel ini adalah studi kepustakaan yang data-datanya diperoleh melalui buku, jurnal, artikel, penelitian dan dokumendokumen yang sesuai dengan tema ini. Hasil: Pemikiran Hasan Langgulung tentang pendidikan Islam kontemporer ialah bahwa belajar sebagai proses untuk mengembangkan berbagai kompetensi peserta didik, mensinergikan berbagai ilmu, kesehatan mental juga aspek yang penting untuk dikembangkan dalam pendidikan Islam selain aspek spiritual, pengetahuan dan sosial. Sedangkan Dzakiah Darajat mempunyai pandangan bahwa pendidikan Islam harus mencetak manusia yang sesuai fitrahnya yakni sebagai Abdullah dan Khalifah Allah, mensinergikan aspek intelektual dan spiritual serta moral, psikologi sufistik sebagai aspek yang perlu dikembangkan di dalam pendidikan Islam. Titik temu antar keduanya ialah bahwa psikologi menjadi sebuah ilmu yang turut membantu pendidik dalam menghadapi berbagai ragam kepribadian peserta didik, dengan memahami ilmu psikologi maka pendidik akan lebih mudah dalam memberlakukan peserta didik. Sehingga psikologi tidak bisa dipisahkan dengan dunia pendidikan Islam.
\end{abstract}

Kata Kunci: Kontemporer, Pendidikan Islam, Hasan Langgulung, Zakiah Darajat. 


\begin{abstract}
This article aims to analyze the thoughts of contemporary Islamic education Hasan Langgulung and Zakiah Darajat who then sought a meeting point between the two. Islamic education must always be updated and improved in the midst of global currents that are so fast, so that it can always exist in responding to various global challenges and needs. The method used in this article is the study of literature whose data is obtained through books, journals, articles, research and documents that fit this theme. Results: Hasan Langgulung's thought about contemporary Islamic education is that learning as a process to develop various competencies of students, synergizing various sciences, mental health are also important aspects to be developed in Islamic education in addition to spiritual, knowledge and social aspects. Whereas Dzakiah Darajat has the view that Islamic education must produce human beings according to their nature, namely as Abdullah and the Khalifah of Allah, synergizing intellectual and spiritual aspects as well as morals, Sufistic psychology as aspects that need to be developed in Islamic education. The meeting point between the two is that psychology becomes a science that helps educators in dealing with a variety of learners' personalities, by understanding psychology it is easier for educators to treat students. So that psychology cannot be separated from the world of Islamic education.
\end{abstract}

Keywords: Contemporary, Islamic Education, Hasan Langgulung, Zakiah Darajat

\title{
Pendahuluan
}

Peran pendidikan Islam tidak akan pernah pupus oleh perubahan zaman. Ia akan senantiasa hidup dan eksis dalam mengawal jalannya kehidupan manusia sampai kepada puncak kebahagiaan dunia dan akhirat. Di tengah perubahan zaman seperti ini, pendidikan Islam tetap dibutuhkan untuk membentengi umat dari berbagai pengaruh luar yang cenderung negatif. Hal ini dapat dipahami karena era modernitas merupakan era di mana semua informasi, berita dan segala hal dapat diakses dengan mudah oleh setiap individu lewat internet, baik yang positif maupun yang negatif, baik oleh golongan tua maupun muda, baik oleh pejabat maupun oleh rakyat biasa. Dibukanya informasi secara global dan luas serta bebas diakses oleh siapa pun tanpa terkecuali ini dapat menimbulkan masalah, yakni banyak di antara mereka yang terkena pengaruh negatif bahkan terpapar paham radikal yang menjadikan mereka ektrimis. Hal tersebut dipersiapkan untuk menghadapi berbagai tantangan global dan daya saing bangsa serta pengaruh-pengaruh negatif lainnya (Baharun, 2016: 243; Mujib, 1993: 134; Azra, 2012:1).

Di sinilah peran pendidikan Islam dapat dimaksimalkan untuk membantu menangkal dan membekali peserta didik agar bisa memfilter setiap informasi yang masuk maupun yang mereka unduh agar mereka terhindar dari pengetahuan, paham dan 
informasi yang salah, sesat maupun yang ekstrim (Anirah, 2007: 240). Pendidikan Islam juga menjadi bentuk pengejawantahan terhadap nilai-nilai agama Islam yang bersumber dari al Qur'an dan al Hadits yang mengedepankan sikap hidup yang proporsional, objektif, seimbang, moderat dan bijaksana. Islam tidak menghendaki sikap hidup yang keras, otoriter, kaku, statis maupun ekstrim yang tidak mau menerima segala perbedaan (Huda, 2015: 167; Anirah, 2007: 238; Sarjono, 2005: 138).

Pendidikan Islam Indonesia secara historis telah memiliki pengalaman bagaimana harus tetap bertahan dalam himpitan arus modernisasi yang kuat tanpa harus kehilangan identitas. Wujud nyata dari pengalaman tersebut adalah adanya upaya untuk mereformasi sistem pendidikan Islam sebagai jawaban atas tantangan kolonialisme dan ekspansi Kristen (Azra, 2000: 99; Steenbrink, 1994: 7). Pendidikan semestinya dijadikan sebagai upaya untuk menjadikan manusia lebih bermartabat dan dijadikan sarana untuk menyadarkan manusia akan arti penting nilai-nilai kemanusiaan. Oleh sebab itu, menurut Sudarwan Danim (2003: 4), agenda utama pendidikan adalah proses memanusiakan manusia menjadi manusia. Proses pemanusiaan tersebut dapat diupayakan melalui berbagai kegiatan pembelajaran yang dapat mendorong tumbuh kembangnya kesadaran nilai-nilai kemanusiaan, di antaranya melalui pendidikan agama. Dalam Undang-Undang No. 20 Tahun 2003 tentang Sistem Pendidikan Nasional pasal 37 ayat 1 dijelaskan bahwa sebagai agenda proses kemanusiaan dan pemanusiaan, pendidikan dapat dipandang dari dua sisi, yaitu: pertama, sebagai proses pendewasaan peserta didik untuk hidup pada alam demokrasi dan, kedua, sebagai proses penyiapan peserta didik memasuki sektor ekonomi produktif. Memposisikan pendidikan sebagai sarana untuk menyiapkan peserta didik memasuki wilayah ekonomi produktif merupakan hal semu, karena proses pembelajaran di sekolah tidak mendorong terbentuknya semangat dan kesadaran peserta didik tentang arti penting kemandirian dan keterampilan dalam menghadapi kehidupan nyata. Sementara itu dunia industri menuntut profil lulusan pendidikan yang mempunyai kualifikasi dan kompetensi sesuai dengan kebutuhan perusahaan. Sebagai akibatnya banyak dunia pendidikan di Indonesia yang berpikir secara pragmatis dengan mengikuti logika "kapitalisme" dan mengabaikan pentingnya membangun kesadaran yang humanis.

Lickona sebagaimana yang dikutip Muhaimin (2005: vii-viii) menjelaskan bahwa untuk mewujudkan pendidikan agama yang efektif bagi peserta didik diperlukan tiga hal: pertama, moral knowing, meliputi: moral awareness, knowing moral values, perspective- 
taking, moral reasoning, desicion making dan self-knowledge; kedua, meliputi: conscience, self-esteem, empathy, loving the good, self control, dan humanity; dan ketiga, Moral action, meliputi: competence, will dan habit. Disamping tiga hal tersebut, Muhaimin menambahkan pentingnya suasana religius dan kontrol sosial yang kuat di madrasah untuk mewujudkan pembelajaran agama yang efektif. Problem pembelajaran agama terletak pada persoalan bagaimana membelajarkan agama tidak sebatas pada aspek pengetahuan tetapi juga penjiwaan dan pengamalan. Dalam konteks bagaimana membelajarkan agama Islam yang utuh, Abdurrahman Mas'ud (2002: 29) menjelaskan bahwa pendidikan Islam pada masa lalu telah memperlihatkan berbagai ragam transformasi budaya Islam-Jawa melalui modelling yang didemontrasikan oleh para Walisongo. Melalui cerita pewayangan, Walisongo mempersonifikasikan para awliya (kekasih Allah) dan para kyai yang sarat dengan pesan-pesan moral dan kesalehan yang relevan dengan budaya lokal. Kesederhanaan, tidak tamak, mengedepankan kepentingan masyarakat dan orang banyak merupakan warisan nilai-nilai luhur yang ditransformasikan oleh Walisongo dan para santrinya. Dalam sebuah rumusan naskah Islam Jawa Klasik misalnya, terdapat ungkapan "arep atatakena elmu, sakadare den lampahaken (carilah ilmu yang bisa engkau praktekkan, terapkan) (Drewes, 1978: 19).

Tentu ungkapan ini mengandung pesan bijak pentingnya belajar ilmu agama Islam yang kemudian diikuti dengan pengamalan. Konsep ilmu yang operasional sudah dikenal sejak dulu dalam tradisi intelektual Islam. Namun demikian, saat sekarang ada kesan praksis pendidikan Islam di madrasah seolah kehilangan akar sejarahnya, khususnya tradisi pesantren yang unik. Dalam tantangan global, kegigihan dalam mempertahankan prinsip-prinsip luhur serta nilai-nilai yang menjunjung tinggi harkat dan martabat kemanusiaan perlu mendapatkan perhatian khusus, karena masyarakat yang gigih dan mempunyai prinsiplah yang dapat bertahan menghadapi gempuran budaya global semakin mengeyahkan nilai-nilai kemanusiaan.

Sjafri Sairin (2002: 35) menegaskan bahwa sistem pendidikan Islam di Indonesia dari masa penjajahan sampai masa kini merupakan bagian tak terpisahkan dari sistem pendidikan nasional. Terjadinya dinamika perubahan dalam sistem pendidikan Islam sejak masa penjajahan hingga kini, menunjukkan indikasi yang kuat bahwa pendidikan Islam dapat menyesuaikan diri dan beradaptasi dengan perkembangan masyarakat. Perubahan tersebut juga menggambarkan bahwa komunitas muslim dapat melakukan 
pembauran dalam sistem pendidikan Islam yang mereka geluti dengan dinamika yang sedang berkembang di masyarakat saat ini.

Oleh karenanya, arus modernitas harus dikawal dengan menguatkan sistem pendidikan Islam secara utuh. Caranya, dengan memperbaiki kualitas pembelajaran di lingkungan pendidikan Islam, meningkatkan pemerataan sarana prasana di lingkungan pendidikan Islam, meningkatkan pengawasan terhadap pelaksanaan pendidikan Islam, mengutamakan aspek afektif dalam penilaian di samping aspek kognitif dan psikomotorik, kesemuanya ini dalam rangka mencegah mereka dari tindakan yang menyimpang. Selain itu, penguatan Pendidikan Islam bisa dilakukan dengan memperbaiki serta meningkatkan pelayanan pendidikan Islam, baik secara internal maupun secara eksternal. Terakhir, pendidikan Islam harus berperan-tampil secara nyata untuk mendidik peserta didik menjadi manusia yang benar-benar manusia sesuai kodratnya sebagai ciptaan Allah swt, agar mampu melahirkan generasi bangsa yang saleh secara spiritual dan saleh secara sosial. Inilah langkah-langkah yang harus dilakukan untuk mereduksi persepsi masyarakat yang yang melihat pendidikan Islam 'sebelah mata.' (Ali, 2016: 75; Nata, 2014: 80-84).

Salah satu cara memperoleh cakrawala pengetahuan mengenai apa dan bagaimana pendidikan Islam serta kontribusinya dalam membangun peradaban dunia, maka kita harus 'menengok' pemikiran para tokoh pendidikan Islam baik dalam negeri maupun luar negeri (dunia). Mengembangkan dan memajukan pendidikan Islam tidak bisa dilakukan dengan hanya sekedar uji coba secara personal, namun dibutuhkan model, desain dan bentuk dari pemikiran seorang tokoh pendidikan. Di tangan merekalah dunia pendidikan Islam telah berkembang dan maju. Oleh karena itu, senarai pemikiran, pandangan dan kerja nyata yang mereka lakukan patut untuk diresapi, dipahami kemudian diaplikasikan di lingkungan pendidikan Islam. Hal ini dilakukan untuk mencari model-sistem pendidikan Islam yang ideal demi kemajuan peradaban Islam di tengah membuncahnya arus modernitas (Jabiri, et.al, 2003: 283).

Di antara para pemikir pendidikan Islam kontemporer ialah Hasan Langgulung dan Zakiah Darajat. Dalam membangun model pendidikan Islam kontemporer maka pendidikan harus mengoptimalkan peran fitrah manusia sebagai makhluk Tuhan, melalui pendayagunaan fitrah manusia maka akan melahirkan berbagai kemampuan-kemampuan yang ada di dalam diri manusia dan semua itu metode dan strateginya ada di dalam dunia 
pendidikan (Firman, 2017: 123; Nizar, 2000: 142-143). Ini menjadi penegasan Langgulung bahwa pendidikan harus bersifat integratif dan holistik yang senantiasa dilandasi nilai-nilai ideal Islam (Susanto, 2010: 129-130). Kemudian, Zakiah Darajat juga mempunyai pandangan bahwa Islam menjadi agama yang membina umat manusia menjadi hamba Allah secara komprehensif yang meliputi perbuatan, pikiran dan perasaan (Darajat, 1995: 35). Pembinaan dan pengajaran yang ideal dalam pendidikan Islam kontemporer ialah yang saling bersinergi yang tidak hanya mengajar, dan memberikan latihan semata tapi juga melakuakn pengawasan dan memberi teladan, model integrasi pemikiran Zakiah Darajat sebagai bentuk untuk menghiasi wajah baru di dunia pendidikan Islam era modern (Mawangir, 2015: 53-56).

Pandangan Hasan Langgulung dan Zakiah Darajat menjadi sumber tokoh pemikir pendidikan yang bisa dikatakan mempunyai gagasan-ide kontemporer yang bisa membantu pendidikan Islam menggapai kemajuan yang kompleks. Keduanya mempunyai visi misi yang ingin menjadikan wajah pendidikan Islam bersifat integratif, komprehensif dan holistik, bukan menjadi pendidikan yang dikotomis. Integrasi keilmuan, transformasi keilmuan dan multidispiner keilmuan menjadi corak dari wajah pendidikan Islam kontemporer (Karwadi, 2009: 137-158; Firmansyah, 2013; Ikah, 2018; Gunawan, 2014: 176; Darajat, 2004: 3).

Berdasarkan beberapa penelitian sebelumnya yang hanya mengfokuskan pada satu aspek kajian dari pemikiran Hasan Langgulung dan Zakiah Darajat, maka dalam penelitian ini akan lebih dikaji secara mendalam untuk menemukan konsep pendidikan Islam kontemporer perspektif Hasan Langgulung dan Zakiah Darajat yang nantinya bisa diintegrasikan untuk menemukan persamaan dan perbedaan antar keduanya yang selanjutnya dapat dijadikan evaluasi, rujukan dan referensi dalam memperbaiki kualitas pendidikan Islam di Indonesia khususnya untuk menjadi lebih baik dan maju lagi di era yang serba cepat ini. Hal tersebut mengharuskan pendidikan Islam harus senantiasa update untuk bisa tetap bertahan di atas segala perubahan zaman. Sehingga, pendidikan Islam tetap dilirik oleh masyarakat karena kemampuannya berdialog dengan zaman, kemampuannya menjawab tantangan, kebutuhan masyarakat serta kesiapannya dalam bersaing dengan pendidikan umum-global. 


\section{Pemikiran Hasan Langgulung tentang Pendidikan Islam Kontemporer}

1. Biografi Hasan Langgulung

Nama lengkapnya adalah Hasan Langgulung, lahir di Rappang, Sulawesi Selatan, pada tanggal 16 Oktober 1934. Ayahnya bernama Langgulung sedangan ibunya bernama Aminah Tansaruh (Rifa'i, 2006: 15). Pada tanggal 22 September 1972, Hasan Langgulung melepas masa lajangnya dengan menikahi seorang perempuan bernama Nur Timah binti Mohammad Yunus. Pernikahannya dikaruniai dua orang putra dan seorang putri, yaitu Ahmad Taufiq, Nurul Huda, dan Siti Zariah (Sudja'i, 1999: 3). Keluarga ini tinggal di sebuah rumah di jalan B 28 Taman Bukit, Kajang, Malaysia. Hasan Langgulung meninggal pada usianya yang ke- 73, tepatnya di Kuala Lumpur pada Sabtu 2 Agustus 2008 pukul 19.47 waktu setempat. Ia meninggal dunia karena penyakit stroke dan dimakamkan di Taman Pemakaman Sentul, Kuala Lumpur (Fauziyah, 2009: 50).

\section{Pemikiran Pendidikan Islam Kontenporer Hasan Langgulung}

Pendidikan Islam kontemporer dimaknai sebagai model pendidikan yang mampu menggagas dan memformat pendidikan Islam sebagai pencetus, penggerak, perubahan, dan pembentukan manusia yang unggul diberbagai aspek, baik aspek moral, sosial, intelektual maupun spiritual (Anwar, 2018: 164). Integritas; keterpaduan berbagai aspek tersebutlah yang juga digagas oleh Hasan Langgulung.

Hasan Langgulung memiliki latar belakang pemikiran dalam bidang pendidikan dan psikologi. Terbukti, banyaknya prestasi yang dihasilkan dalam bidang ini. Dari karyakaryanya, bisa terlihat Hasan Langgulung merupakan seorang yang kompeten dalam bidang pendidikan dan psikologi. Pendidikan menurut Hasan Langgulung bisa dilihat dari dua sudut pandang, yakni sudut pandang individu dan masyarakat. Dalam sudut pandang individu, pendidikan adalah proses penggalian harta potensi yang dimiliki individu. Sedangkan dari sudut pandang masyarakat, pendidikan adalah proses penyaluran nilainilai budaya dari generasi tua ke generasi muda. Maka, peran psikologi pun adalah sebagai alat dalam proses berjalannya sebuah pendidikan khususnya pendidikan Islam (Langgulung, 2000: 427).

Integrasi pendidikan dan psikologi menjadi model pemikirannya yang kontemporer dimana mensinergikan antara aspek intelektual dan mental, yang nantinya akan mengaraha kepada moral dan sosial dengan panduan agama. mengingat, psikologi 
menjadi sebuah ilmu yang turut membantu pendidik dalam menghadapi berbagai ragam kepribadian peserta didik, dengan memahami ilmu psikologi maka pendidik akan lebih mudah dalam memberlakukan peserta didik, mengingat yang mereka hadapi tak lain adalah manusia. Sehingga, psikologi dalam pendidikan Islam sangat diperlukan dan itu terbukti di saat seseorang mengambil jurusan guru khususnya guru agama Islam (PAI), maka ia pasti mendapat mata kuliah psikologi. Mulai psikologi perkembangan, ilmu psikologi, psikologi pembelajaran dan psikologi pendidikan (Qussy, 1974: 138; Darajat, 1986; Yusuf, 2018).

Pemikiran Hasan Langgulung tentang pendidikan Islam kontemporer dapat kita telaah dari tiga aspek, di antaranya: Pertama, perkembangan potensi individu. Adanya sebuah proses belajar yang merupakan gejala dari pendidikan, dalam pandangan Hasan Langgulung adalah proses penggarapan potensi individu sebanyak-banyaknya. Di dalam dirinya manusia menyimpan segudang potensi yang perlu diwujudkan atau diaktualisasi dalam kehidupan bermasyarakat. Hasan Langgulung memetakan tiga kategori potensi manusia, yakni aspek kognitif, psikologis, dan jasmaniah (Langgulung, 2000: 297). Ketiga aspek inilah dalam proses perkembangan mengalami tiga tahap, yakni asimilasi, akomodasi, dan keseimbangan.

Hasan Langgulung dalam hal ini merespon terhadap Islamisasi pengetahuan, berusaha mengintegralkan konsep psikologi, yang secara kenamaan dipopulerkan oleh pemikir-pemikir Barat, dengan pendidikan Islam. Bahwasanya psikologi, yang secara hakikat merupakan kajian tentang kejiwaan ('aql, nafs, ruh, dan qalb), mempunyai implikasi terhadap proses pendidikan.

Pendidikan Islam secara dalam bingkai psikologi, sebagai proses pembinaan terhadap potensi-potensi yang sudah ada. Maka, dalam pendidikan Islam pun perlu ada konsep epistemologi dalam mengintegralkan nilai-nilai Islam dan ilmu modern. Dalam peta pemikiran Hasan Langgulung, seorang pakar dalam dunia pendidikan Islam abad 20 dengan kecenderungan spesialisasi dalam bidang psikologi pendidikan, pendidikan seharusnya mempunyai fondasi yang kuat. DiiBaratkan sebuah rumah, setidaknya harus memiliki fondasi, dinding, atap, tiang, dan lain-lain. Begitu juga dengan pendidikan, perlu adanya kurikulum yang bijak, konseling, administrasi yang bagus, pengajaran, dan penilaian. Setidaknya, ada 6 unsur menurut Langgulung yang bisa dijadikan fondasi atau 
asas-asas dalam sebuah pendidikan, yakni landasan dasar filsafat, sejarah, politik, sosial, ekonomi, dan psikologi (Taufiq, 2014: 2).

Kedua, belajar menurut Hasan Langgulung adalah sebuah gejala dalam proses pendidikan. Tujuan dari belajar pun adalah senada dengan tujuan dari pendidikan, di mana individu bisa mengaktualisasikan segala potensi yang dimiliki dalam kehidupan sehari-hari (Langgulung, 2000: 24-25). Teori belajar behavioristik, Hasan Langgulung menamakannya dengan istilah "teori asosiasi". Teori ini melibatkan sebuah rangsangan dalam mempengaruhi, di mana munculnya sebuah respons dari individu dan pertautan (connection) antara rangsangan dengan respons, atau sering disebut pertautan S-R. Sedangkan teori kognitif, Hasan Langgulung menamakannya dengan istilah "teori lapangan".

Teori ini menjelaskan adanya totalitas unsur-unsur, seperti, banyaknya rangsangan, pola-pola yang bergabung dalam rangsangan, reaksi makhluk hidup, dan makhluk hidup itu sendiri. Unsur-unsur tersebut akan membentuk struktur kognitif individu, di mana adanya sebuah perubahan dalam mengamati objek-objek dan suasanasuasana dengan cara yang baru (Langgulung, 2000: 281-285). Dalam teori proses belajar ala Hasan Langgulung, ditawarkan sebuah cara belajar dengan memperhatikan keadaan lingkungan, baik dalam tingkatan mikro, yakni masyarakat maupun tingkatan makro, yakni antar peradaban (Langgulung, 2000: 289).

Gagasan Hasan Langgulung tentang teori proses belajar hanya merupakan penguatan sebelumnya dengan teori belajar ala psikolog Barat. Hanya saja, Hasan Langgulung menambahkan semangat nilai-nilai Islam di dalamnya. Adapun nilai-nilai Islam tersebut, sebagaimana Hasan Langgulung mengutip pendapat Abdullah Darraz diklasifikasi dalam lima kategori, di antaranya, nilai akhlak perseorangan (alakhlaq alfardhiyyah), nilai akhlak keluarga (akhlaq al-usariyah), nilai akhlak sosial (akhlaq alijtimaiyah), nilai akhlak negara (akhlaq al-daulah), serta nilai akhlak agama (akhlaq aldiniyah). Dari kelima akhlak tersebut, Hasan Langgulung meringkasnya dengan istilah "taqwa" atau dengan kata lain taqwa merupakan himpunan nilainilai yang ada di dalam Islam, dan sebagai implikasinya terhadap pendidikan Islam, seorang pemeluk (maksudnya : individu, peserta didik, dan pendidik) harus menghayati nilainilai tersebut (Langgulung, 2000: 415). 
Ketiga, kesehatan mental dalam pendidikan Islam. Pendidikan Islam merupakan konsep pendidikan yang berlandaskan pada sumber al Qur`an dan as Sunnah. Tentunya dalam pendidikan Islam ada tujuan yang diharapkan, yakni membentuk kepribadian yang utama. Dalam membentuk kepribadian utama, ada faktor yang sangat penting, salah satunya mempunyai jiwa yang sehat, di mana dalam kajian psikologi sering dinamakan kesehatan mental (mental healty) sehingga terlahirlah salah satu cabang disiplin ilmu psikologi yakni psikologi kepribadian atau psikologi syakhsiyah (Langgulung, 1986: 295).

Peran pendidikan dalam pengembangan potensi manusia, problematika belajar, dan pembinaan mental yang sehat, kesemuanya sebagai tolak ukur dalam pencapaian tujuan dari pendidikan Islam. Tujuan sejati dalam pendidikan Islam menurut Hasan Langgulung, sebagaimana pembahasan-pembahasan sebelumnya adalah sebagai nilai aktualisasi potensi manusia agar bisa bebas dengan diawasi oleh nilai-nilai Islam. Dalam Islam, sebagaimana amanah QS adz-Dzariyat: 56 (Langgulung: 2004: 50). Manusia mempunyai tanggung jawab untuk beribadah. Ibadah tersebut sebagai bukti pengakuan penciptaan juga sebagai syarat dalam mengaktualisasikan diri.

Penekanan Hasan Langgulung mengarah kepada pengintegrasian dan keterpaduan aspek moral, sosial, mental, intelektual dan spiritual, sehingga pembelajaran dan pendidikan tidak hanya berorientasi pada kognitif semata, namun juga kepada afektif, psikomotorik yang didukung oleh kecerdasan mental dan spiritual yang kuat. Oleh karenanya, pemikirannya sangat signitifkan terhadap gaya pendidikan Islam modern di tengah zaman yang semakin dinamis. Untuk itu, model pemikiran kontemporer Hasan Langgulung bisa dikatakan senada dengan konsep pendidikan holistik (Chaer, 2020; Musfah, 2012: 2-5; Primani \& Khairunnas, 2016: 27-40) dan pendidikan integratif (Purnama, 2020: 20; Zuchdi, 2009: 36; Istiarsono, 2016: 3; Suyanto \& Abbas, 2004: 32). Ini menjadi landasan bahwa format pendidikan Islam yang digagas oleh Hasan Langgulung bersifat kontemporer sesuai dengan zaman post modern saat ini.

Berikut peta konsep pemikiran pendidikan Islam kontemporer Hasan Langgulung: 


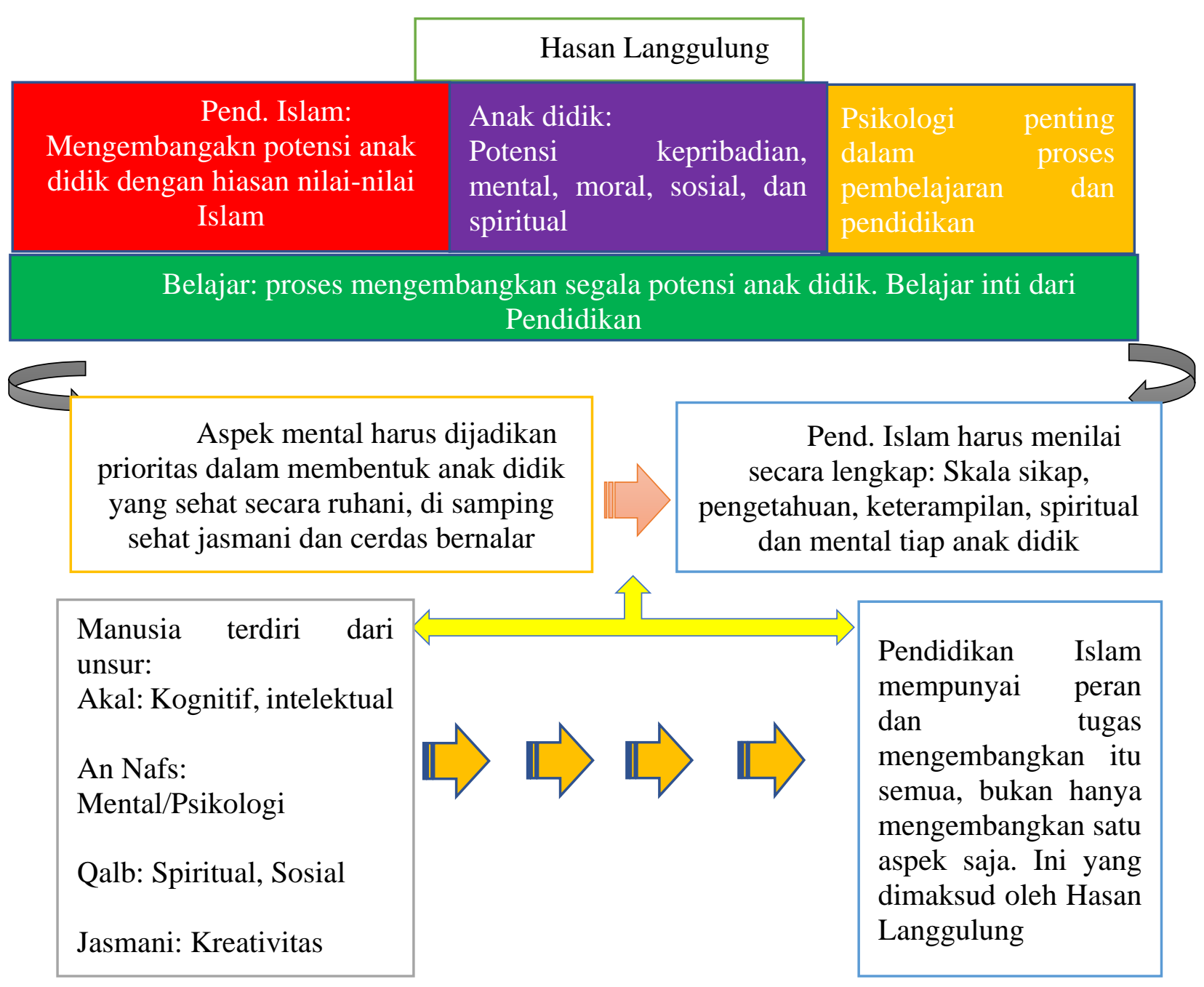

Gambar 1: Peta Konsep Pemikiran Pend. Islam Kontemporer Hasan Langgulung

\section{Pemikiran Zakiah Darajat tentang Pendidikan Islam Kontemporer}

1. Biografi Zakiah Darajat

Nama aslinya adalah Zakiah Daradjat, ia lahir pada tanggal 6 November 1929, di Bukittinggi, Provinsi Sumatera Barat (Bainar, 1997: 117). Pendidikan awal yang pernah diduduki oleh Zakiah, selagi Zakiah berada dekat dengan orang tuanya dan saudarasaudaranya, yaitu jenjang pendidikan yang berawal dari sekolah Standard School Muhammadiyah Bukittinggi. Kemudian ke Kuliyatul Mubalighat Muhammadiyah Padang Panjang, tamat pada tahun 1947. Bahkan meneruskan ke SMA bagian B TDR (Ilmu Pengetahuan Alam) pemuda, Bukit tinggi, tamat tahun 1951 (Darajat, 1984: 63).

Zakiah bertekad meninggalkan kampung halamannya, pergi merantau ke Yogyakarta, untuk melanjutkan studinya ke perguruan tinggi. Setamat Doktoral I, 
Fakultas Tarbiyah PTAIN Yogyakarta, Zakiah pun mendapat tawaran untuk melanjutkan studi di Mesir. Di Mesir Zakiah memasuki Perguruan yang bernama "Ein Shams". Zakiah mengambil jurusan "Special Diploma for Education" University Fakulty of Education Cairo dapat diselesaikannya dan tamat tahun 1958. Zakiah tidak berhenti sampai di situ saja, tetapi melanjutkan ke Magister Pendidikan Jurusan "Spesialisasi dalam Mental Hygiene" tamat pada tahun 1959. Terus sampai melanjutkan ke tingkat Doktor (Ph.D) Pendidikan, jurusan "Spesialiasi Psycho-Terapy", selesai pada tahun 1964 (Darajat, 1984: 63).

\section{Pemikiran Pendidikan Islam Kontemporer Zakiah Darajat}

Pemikiran pendidikan Islam kontemporer juga terlihat dari gagasan dan ide-ide Zakiah Darajat dengan konsep mengharmonisasikan aspek mental dengan spiritual serta moral dalam proses pembelajaran. Artinya, pembelajaran yang diinginkan oleh Zakiah Darajat tidak yang bersifat monoton dan fokus pada satu aspek. Disini letak integrasi pendidikan Islam yang berbasis multidisipliner (Bagir, 2005: 47; Yamin, 2009: 15-16; Rusdiana, 2014: 123; Muhaimin, 2011). Zakiah Darajat sebagai intelektual Muslimah yang banyak menyumbangkan gagasan, karya dan ide-ide cemerlangnya bagi dunia pendidikan Islam. Gagasannya sangat penting untuk terus ditelaah dan dikaji di dunia pendidikan Islam untuk memberikan agin segar terhadap suasana ilmiah di lingkungan lembaga pendidikan Islam di Indonesia yang lebih baik lagi.

Dalam pandangan Zakiah Daradjat, pendidikan Islam mempunyai tujuan yang jelas dan tegas. Menurut Zakiah, Islam memiliki tujuan yang jelas dan pasti, yaitu untuk membina manusia agar menjadi hamba Allah yang saleh dengan seluruh aspek kehidupannya yang mencakup perbuatan, pikiran, dan perasaan (Darajat, 1995: 35). Ungkapan di atas bila ditelusuri lebih jauh akan memiliki implikasi dan cakupan yang cukup luas. Membina manusia merupakan sebuah upaya untuk mengajar, melatih, mengarahkan, mengawasi, dan memberi teladan kepada seseorang untuk mencapai tujuan yang telah ditentukan. Pembinaan yang hanya memberikan pelajaran, latihan, dan arahan akan menciptakan manusia yang tidak berjiwa. Sementara, pembinaan yang hanya memberikan pengawasan dan teladan akan menciptakan manusia yang kurang kreatif.

Oleh karena itu, pembinaan yang baik mestinya mencakup semua upaya tersebut di atas. Dalam pembinaan tersebut diarahkan kepada pembentukan seorang hamba Allah 
yang saleh. Untuk mencapai tingkatan yang saleh ini, penanaman nilai-nilai agama menjadi syarat utama (Darajat, 1993: 56). Tanpa penanaman nilai-nilai agama, pencapaian pembentukan hamba Allah yang saleh menjadi sangat jauh. Seorang hamba yang saleh berarti dia menyadari kedudukannya di dunia, yakni di samping sebagai khalifah Allah di bumi juga sebagai hamba Allah yang harus beribadah kepada- Nya. Kesadaran yang demikian ini akan muncul bila seseorang telah benar-benar mengerti, memahami, dan menghayati ajaran-ajaran agama Islam.

Selanjutnya, tujuan pendidikan menurut Zakiah juga agak berbeda dengan tujuan pendidikan Nasional yang lebih menekankan pada aspek kecerdasan (intelektual) dan pengembangan manusia seutuhnya (Gunawan, 1995, 163). Di samping itu, rasa tanggung jawab yang dikembangkan hanya mengarah kepada masyarakat dan bangsa. Oleh karena itu, dalam pelaksanaanya, Pendidikan Nasional kurang bertanggung jawab terhadap Tuhan Yang Maha Esa. Inilah yang barangkali sedikit membedakan antara tujuan pendidikan Islam bagi Zakiah. Landasan pendidikan Islam menurut Zakiah adalah al Qur'an, al-Sunnah, dan Ijtihad (Faruqi, 1984: 47). Pendapat Zakiah bahwa pada dasarnya tujuan pendidikan Islam adalah membentuk manusia muslim yang sehat mentalnya (Darajat, 1982: 17). Mental merupakan aspek yang cukup penting, di samping aspek spiritual, sosial dan moral. Mental yang sehat akan menjadi pribadi yang mampu mengolah daya emosionalnya dan daya nalarnya akan senantiasa setabil. Sehingga, bisa melakukan kegiatan ilmiah, penelitian dan observasi yang berkaitan dengan pembelajaran dan pendidikan.

Sedangkan kesehatan mental merupakan salah satu sub ilmu jiwa (psikologi). Untuk lingkungan pendidikan Islam bagi Zakiah ada tiga yaitu keluarga yang menjadi tanggung jawab orang tua, sekolah yang menjadi tanggung jawab para guru atau dosen, dan masyarakat yang menjadi tanggung jawab masyarakat dan pemerintah. Sedang kurikulum pendidikan Islam, menurut Zakiah (1982: 36) tidak mengenal istilah dikotomi. Istilah tersebut muncul merupakan keberhasilan dan warisan penjajah Belanda yang beruasaha untuk memisahkan secara tegas antara ilmu agama dan ilmu modern (umum). Agar dikotomi tersebut semakin berkurang, maka Zakiah telah memprakarsai disusunnya buku-buku daras ilmu umum dengan pendekatan agama Islam. Langkah Zakiah tersebut sebagai usaha mensinergikan agama dan ilmu pengetahuan untuk bisa dimanfaatkan serta 
dikembangkan oleh dunia pendidikan dengan tujuan agar kompetensi lulusan dari pendidikan Islam bisa menjawab tantangan dunia, selain menjawab isu-isu agama.

Pendidikan dalam pemahaman Zakiah mencakup kehidupan manusia seutuhnya, tidak hanya memperhatikan segi akidah saja, juga tidak memperhatikan segi ibadah saja, tidak pula segi akhlak sama. Akan tetapi jauh lebih luas dan lebih dalam daripada itu semua. Dengan kata lain, bahwa pendidikan Islam harus mempunyai perhatian yang luas dari ketiga segi di atas (Darajat, 1995: 98-99). Hal ini menjadi titik tekan Zakiah sebab proses pendidikan nasional pada umumnya dan pendidikan Islam khususnya memberi fokus yang lebih besar pada salah satu segi dari ketiga segi tersebut.

Menurut Zakiah konsep pendidikan Islam adalah sebagai berikut: pertama, pendidikan Islam mencakup semua dimensi manusia sebagaimana ditentukan Islam; kedua, pendidikan Islam menjangkau kehidupan di dunia dan kehidupan di akhirat secara seimbang; ketiga, pendidikan Islam memperhatikan manusia dalam semua gerak kegiatannya, serta mengembangkan padanya daya hubungan dengan orang lain; keempat, pendidikan Islam berlanjut sepanjang hayat, mulai manusia sebagai janin dalam kandungan ibunya, sampai kepada berakhirnya hidup di dunia; dan kelima, dengan melihat ungkapan di atas, maka kurikulum pendidikan Islam menghasilkan manusia yang memperoleh hak di dunia dan hak di akhirat nanti (Darajat, 1996: 35; Tafsir, 1995: 98).

Pendidikan Islam, bagi Zakiah adalah sebagai wahana pembentukan manusia yang berakhlak mulia. Akhlak adalah pantulan iman yang berupa perilaku, ucapan, dan sikap atau dengan kata lain akhlak adalah amal saleh. Iman adalah maknawi (abstrak) sedangkan akhlak adalah bukti keimanan dalam bentuk perbuatan yang dilakukan dengan kesadaran dan karena Allah semata (Darajat, 1996: 67).

Kesalehan dan kebagusan akhlak merupakan ciri dari pendidikan Islam, namun tidak semata-mata hanya kedua aspek tersebut yang dikembangkan. Dalam pendidikan Islam sendiri aspek intelektual dan kreativitas juga mendapat perhatian untuk dikembangkan. Hal tersebut sebagai usaha integratif dan komprehensif yang dilakukan oleh pendidikan Islam demi mencetak kader agama-bangsa yang kompleks, sehingga bisa menjawa kebutuhan spiritual, sosial, moral, ekonomi, teknologi bahkan politik masyarakat. Bukan menjadidi generasi bangsa yang hanya pandai masalah-masalah agama semata. Ini yang harus dipublikasikan kepada masyarakat umum, agar tidak lagi 
memandang pendidikan agama Islam sebagai pendidikan yang menjurus kepada akhirat. Paradigma yang demikian harus segera diganti dan diubah, bahwasannya pendidikan Islam juga bisa mengembangkan IPTEK, seni, sains dan beragam keahlian lainnya.

Pemikiran Zakiah Darajat jika kita telaah secara mendalam memang bersifat psikologis spiritualis (psikologi sufistik). Ini disebabkan karena pendidikan hadir untuk memanusiakan manusia, mengembangkan segala potensi manusia dan mengolah segala kompetensi yang ada di dalam jiwa tiap manusia (peserta didik). Ilmu yang membahas secara lengkap masalah manusia adalah ilmu psikologi. Kemudian, usaha memanusiakan manusia, mengembangkan potensi dan kompetensi tiap peserta didik ini diarahkan kepada tugas, peran dari penciptaan manusia itu sendiri. Dalam hal ini masuk wilayah spiritual. Artinya, bahwa pendidikan Islam ingin mengembalikan manusia kepada jati dirinya sebagai ciptaan Allah, hamba Allah dan wakil-Nya di muka bumi. Bukan menjadikan manusia yang berhasil mengembangkan ilmu pengetahuan dan teknologi lalu meninggalkan agama, lalai akan tugas dan perannya sebagai hamba dan wakil Allah. Letak nilai spiritualnya di sini, sehingga pendidikan Islam tetap dan harus mengembangkan segala potensi anak didik semaksimal mungkin dengan ikatan sendisendi agama, agar tidak menjadi manusia yang angkuh, sombong, dan murtad dari agama. Melainkan manusia yang tetap mengakui Allah sebagai Tuhannya meskipun ia berhasil mengenggam dunia di tanganya, pribadi yang luhur, rendah hati, dan menjunjung tinggi persaudaraan, keharmonisan dan kemaslahatan manusia secara universal. Ini yang disebut memanusiakan manusia, tujuannya agar ia tetap berada di batas-batas yang telah ditentukan Allah swt, yakni sebagai seorang makhluk (ciptaan) Allah.

Ini menjadi penegasan bahwa model pemikiran pendidikan Islam Zakiah Darajat bisa dikontruksikkan dengan suasana pendidikan Islam saat ini, sehingga ditemukan persamaan dan kolerasi terhadap pembenahan, perbaikan dan kemajuan pendidikan Islam yang lebih baik. Zakiah Darajat menginkan adanya pembelajaran-pendidikan yang komprehensif dengan mensinergikan berbagai dimensi, kekuatan dan kompetensi yang akhirnya menjadikan lulusan pendidikan Islam menjadi generasi yang produktif yang bisa bersaing di tengah dinamika zaman (Roqib, 2009: 61; Prasetyo, 2018: 80; Rif'an, 2018: 19). 
Berikut peta konsep Zakiah Darajat mengenai pemikiran pendidikan Islam kontemporernya:

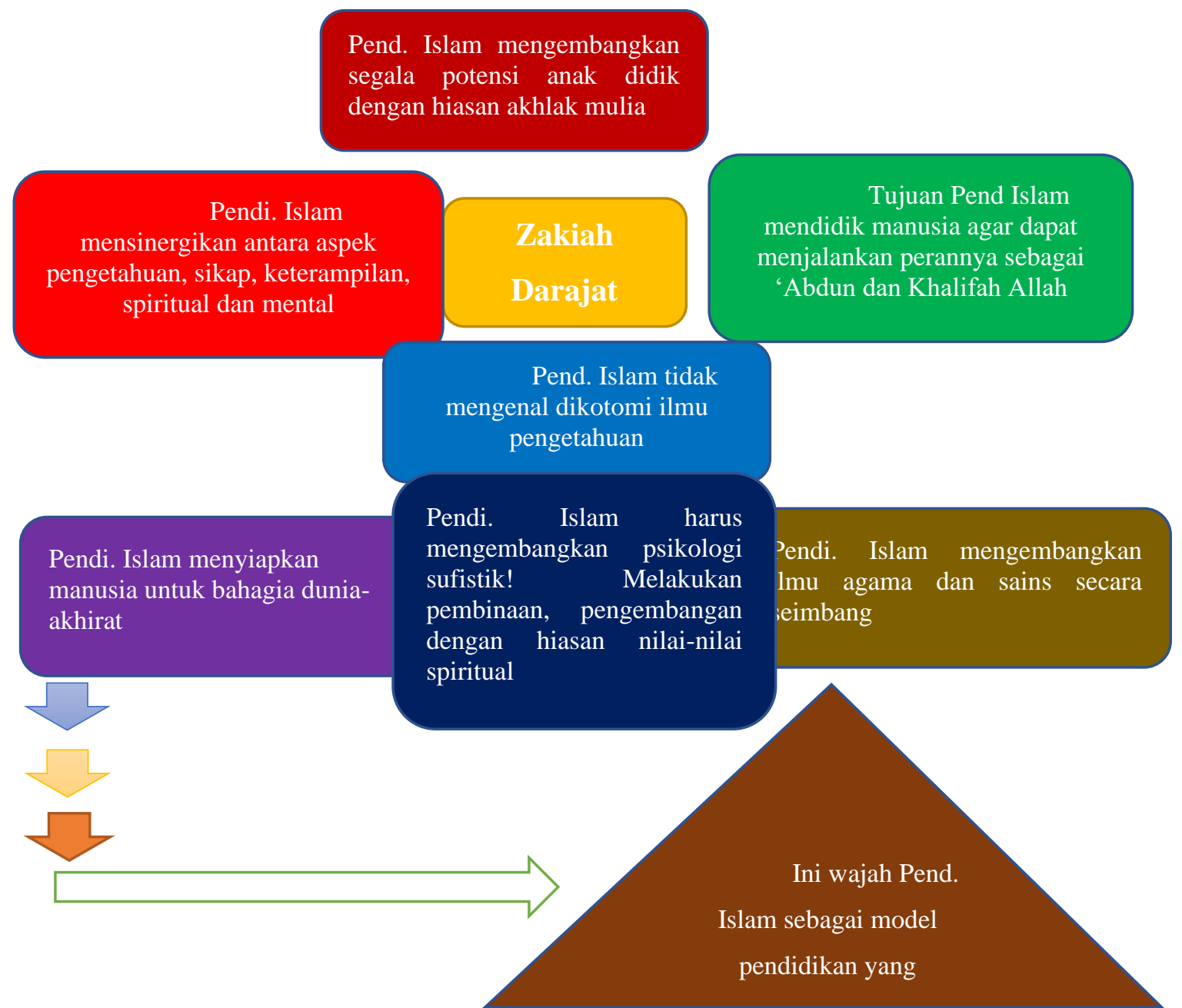

Gambar 2: Peta Konsep Pemikiran Pend. Islam Kontemporer Zakiah Darajat

\section{Titik Temu Pemikiran Hasan Langgulung dan Zakiah Darajat terkait Pendidikan Islam Kontemporer}

Pemikiran pendidikan Islam kontemporer yang digagas oleh Hasan Langgulung dan Zakiah Darajat mempunyai kolerasi yang signifikan khususnya terkait masalah psikologi (mental). Artinya bahwa pendidikan Islam tidak hanya fokus pada proses pembelajaran semata yang mengarah kepada aspek pengetahuan, pembiasaan yang mengarah pada aspek sikap dan kreativitas yang mengarah pada aspek psikomotorik. Namun juga harus memperhatikan keadaan psikologi peserta didik. Pendidikan Islam 
mempunyai tugas juga untuk mengembangkan potensi psikologi peserta didik yang diarahkan pada dimensi spiritual. Upaya tersebut sebagai bentuk dalam menanamkan nilai-nilai keIslaman pada diri peserta didik, sehingga akan menjadi anak yang bisa mengendalikan emosinya, perasaannya dan keadaan mentalnya.

Pendidikan Islam harus mampu melahirkan lulusan yang cakap dalam berbagai bidang, baik cakap dalam bidang intelektual, sosial, moral, spiritual dan mental. Tidak menjadi lulusan yang hanya cerdas, sopan santun, dan berjiwa religi semata, namun juga lulusan yang bisa mengontrol jiwanya untuk senantiasa stabil. Hal tersebut sebagai aktualisasi bahwa pembelajaran adalah upaya untuk mengembangkan segala potensi dalam diri peserta didik.

Aspek psikologi yang dibalut dengan nilai-nilai Islam sebagai bentuk gagasan Hasan Langgulung dan Zakiah Darajat menunjukkan langkah mengintegrasikan ilmu psikologi dengan ilmu Islam di satu sisi, di sisi lain sebagai upaya untuk membentuk peserta didik yang sehat secara jasmani dan ruhani dengan balutan moralitas dan spiritualitas yang tinggi.

Psikologis secara singkat diartikan sebagai studi tentang tingkah laku dan hubungan antar manusia. Kelakuan seorang individu tidak saja terdiri atas perbuatanperbuatan yang dapat dilihat akan tetapi semua reaksi terhadap semua keadaan di dalam dan pengaruh dari berbagai faktor lingkungan (Kasijan, 1984: 12). Pendidikan Islam sebagai bentuk pendidikan yang menyelenggarakan proses penggalian, pembentukan, pendayagunaan dan pengembangan daya pikir, zikir, dan kreasi manusia melalui pengajaran, bimbingan, latihan, pengarahan dan pengabdian yang dilandasi dan dinafasi oleh ruh ajaran Islam, sehingga terbentuk muslim yang sejati, mampu mengontrol, mengatur, mengawasi diri sebagai implementasi dari tugasnya sebagai hamba dan wakil Allah di bumi (Bawani, 1991: 79). Oleh karenanya, pendidikan Islam dan psikologi tidak bisa dipisahkan. Mengingat, peran psikologi dalam pendidikan Islam adalah menjembatani proses penyampaian ilmu pengetahuan agar lebih memperhatikan aspek psikologi masing-masing peserta didik. Hal ini akan sangat menentukan keberhasilan proses transfer of values peserta didik (Hadi, 2017: 253).

Gagasan Hasan Langgulung dan Zakiah Darajat terkait aspek psikologi yang harus diperhatikan oleh pendidikan Islam, ini memiliki dasar bahwa pandangan al Qur'an 
terhadap manusia adalah pandagan yang menyeluruh, terpadu dan seimbang. Manusia bukan hanya berupa wujud materi yang terdiri atas fisika, kimia, dan otot-otot mekanis. Manusia juga bukan makhluk yang hanya ruh yang terlepas dari raga. Manusia menurut al Qur'an adalah makhluk yang terdiri atas jiwa dan raga yang keduanya saling berhubungan dan saling mempengaruhi. Untuk itu, manusia mendapatkan posisi makhluk yang paling mulia. Keutamaan dan kelebihannya ini jangan sampai jatuh yang berakibat pada keadaan hina manusia itu sendiri, sehingga diperlukan sebuah jalan untuk menjaga dan mengontrol serta mengembangkan keutamaan tersebut yakni melalui pendidikan Islam (Bernadib, 1987: 4). Dengan jalan pendidikan Islam inilah manusia akan dapat mengembangkan segala potensinya dan menjaga keutamannya sehingga menjadi manusia yang mulia di sisi Allah swt.

Hal tersebut diperkuat bahwa pendidikan khususnya pendidikan Islam sebagai suatu proses panjang untuk mengaktualisasikan seluruh potensi diri manusia sehingga potensi kemanusiaannya menjadi aktual. Dalam proses mengaktulisasikan diri tersebut diperlukan pengetahuan tentang keberadaan potensi, situasi, dan kondisi lingkungan yang tepat untuk mengaktulisasikannya. Pengetahuan tentang diri manusia dengan segenap permasalahannya dibahas dalam dunia psikologi, sehingga pendidikan dan psikologi merupakan dua hal yang tidak dapat dipisahkan (Mubarak, 2017: 215; Shihab, 1996: 45; Syah, 2003: 76; Ulwiyah, 2015: 76-99). 
Berikut penulis gambarkan titik temu antara pemikiran Hasan Langgulung dan Zakiah Darajat:

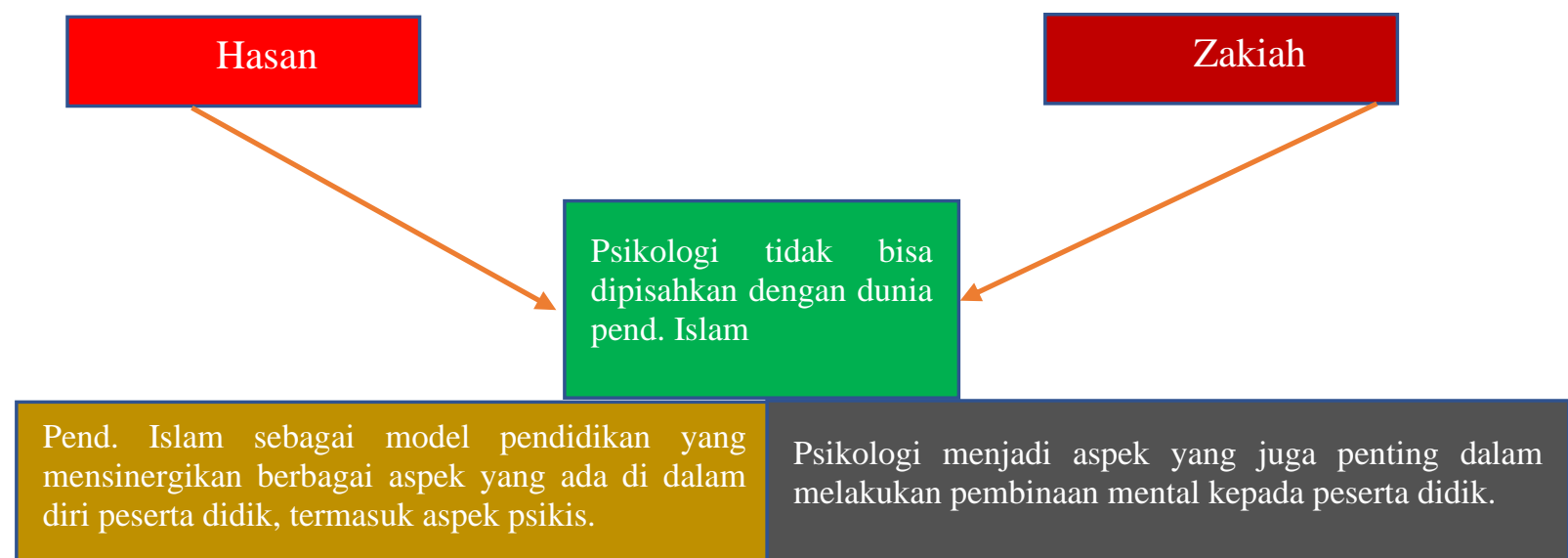

Dengan memahami psikologi, pendidik akan bisa mengenal berbagai kepribadian masing-masing peserta didik. Sehingga bisa memperlakukan mereka dengan baik

Gambar 3: Peta Konsep mengenai titik temu antara pemikiran Hasan Langgulung dan Zakiah Darajat tentang Pend. Islam Kontemporer

Dari paparan penelitian ini dapatlah diambil beberapa kesimpulan, di antaranya: Pertama, pemikiran Hasan Langgulung Pemikiran Hasan Langgulung tentang pendidikan Islam kontemporer ialah bahwa belajar sebagai proses untuk mengembangkan berbagai kompetensi peserta didik, mensinergikan berbagai ilmu, kesehatan mental juga aspek yang penting untuk dikembangkan dalam pendidikan Islam selain aspek spiritual, pengetahuan dan sosial. Kedua, Dzakiah Darajat mempunyai pandangan bahwa pendidikan Islam harus mencetak manusia yang sesuai fitrahnya yakni sebagai Abdullah dan Khalifah Allah, mensinergikan aspek intelektual dan spiritual serta moral, psikoogi sufistik sebagai aspek yang perlu dikembangkan didalam pendidikan Islam. Ketiga, titik temu antar keduanya ialah bahwa psikologi menjadi sebuah ilmu yang turut membantu pendidik dalam menghadapi berbagai ragam kepribadian peserta didik, dengan memahami ilmu psikologi maka pendidik akan lebih mudah dalam memberlakukan peserta didik. Sehingga psikologi tidak bisa dipisahkan dengan dunia pendidikan Islam. 


\section{DAFTAR PUSTAKA}

Al Faruqi, Isma'il Raji. Islamisasi Pengetahuan. Bandung: Penerbit Pustaka. 1984.

Al Quusy, Abdul Aziz. Pokok-pokok Kesehatan Jiwa; Mental. Jakarta: Bulan Bintang. 1974.

Ali, Mudzakkir. Ilmu Pendidikan Islam. Semarang: PKP12 Universitas Wahid Hasyim. 2016

Anirah, Andi. "Pendidikan Dalam Perspektif Sosio-Kultural, Jurnal Hunafa, Vol. 4, No. 3 (2007): 240.

Anwar, Khairul. "Pendidikan Islam Kontemporer: Antara Konsepsi dan Aplikasi”. Tesis: Pascasarjana UIN Raden Intan Lampung. 2018.

Azra, Azyumardi. Pendidikan Islam Tradisi dan Modernisasi di Tengah Tantangn Milenium III. Jakarta: Kencana. 2012.

Pendidikan Islam: Tradisi dan Modernisasi Menuju Milenium Baru. Ciputat: Logos, 2000.

Bagir, Zainal Abidin. Integrasi Ilmu dan Agama; Interpretasi dan Aksi. Bandung: Mizan. 2005. Yamin, Moh. Menggugat Pendidikan Indonesia. Yogyakarta: Ar Ruzz Media. 2009

Baharun, Hasan. "Manajemen Kinerja Dalam Meningkatkan Competitive Advantage pada Lembaga Pendidikan Islam", Jurnal at Tajdid, Vol. 5, No. 2 (2016): 243.

Bainar. Kiat Sukscs Wanita Indonesia. Jakarta: Perkasa Pres, 1997.

Bawani, Imam. Cendekiawan Muslim dalam Perspektif Pendidikan Islam. Surabaya: Bina Ilmu Offset, 1991.

Bernadib, Imam. Filsafat Pendidikan. Yogyakarta: Fakultas Ilmu Pendidikan. 1987.

Chaer, Thoriqul. et.al. Membangun Pendidikan Indonesia Berkelas Dunia. Kuningan: Goresan Pena. 2020.

Choiri, Moh. Miftachul Dan Aries Fitriani. "Problematika Pendidikan Islam Sebagai Sub Sistem Pendidikan Nasional Di Era Global". Al-Tahrir. Vol.11. No. 2, (2011): 308.

Danim, Sudarwan. Agenda Pembaruan Sistem Pendidikan. Yogyakarta: Pustaka Pelajar, 2003.

Daradjat, Zakiah. Pendidikan Agama dalam Pembinaan Mental. Jakarta: Bulan Bintang, 1982.

"Kesehatan Mental, Peranannya dalam Pendidikan dan Pengajaran". Makalah Seminar disampaikan pada Upacara Pengukuhan Guru Besar Tetap dalam Ilmu Jiwa pada IAIN Syarif Hidayatullah, Jakarta, 27 Agustus 1984.

. Ilmu Jiwa Agama. Jakarta: Bulan Bintang, 1993.

Pendidikan Islam dalam Keluarga dan Sekolah. Jakarta: YPI Ruhama, 1995. 
2004.

Metodik Khusus Pengajaran Agama Islam. Jakarta: Bumi Aksara. . Pendidikan Islam dalam Keluarga dan Sekolah. Jakarta: YPI Ruhama. 1995.

Drewes, G.W.J. An Early Javanese Code of Muslim Ethics. The Hague: KITL V Nijhoff Bibliotheca Indonesia, 1978.

Fauziyah, Ulul. "Pendidikan Islam dalam Prespektif Hasan Langgulung" Skripsi: Fakultas Tarbiyah UIN Maulana Malik Ibrahim Malang, 2009.

Firman, Arham Junaidi. "Paradigma Hasan Langgulung Tentang Konsep Fitrah Dalam Pendidikan Islam”. Jurnal Uhamka, Vol. 8, No. 2 (November 2017): 123.

Firmansyah. "Kesehatan Mental Islam dalam Pendidikan Islam Menurut Pemikiran Hasan Langgulung". Tesis: UIN Sumatera Medan. 2013.

Furchan, Arief dan Agus Maimun. Studi Tokoh, Metode Penelitian Mengenai Tokoh. Yogyakarta: Pustaka Pelajar. 2005.

Gunawan, Ari H. Kebijakan-kebijakan Pendidikan di Indonesia. Jakarta: Rineka Cipta. 1995.

Gunawan, Heri. Pendidikan Islam Kajian Teoritis dan Pemikiran Tokoh. Bandung: PT Remaja Rosdakarya. 2014.

Hadi, Imam Anas. "Peran Penting Psikologi Dalam Pendidikan Islam". Nadwa, Vol. 11. No. 2 (2017): 253.

Huda, Miftahul. "Peran Pendidikan Islam Terhadap Perubahan Sosial”, Edukasia: Jurnal Penelitian Pendidikan Islam, Vol. 10, No. 1 (2015): 167.

Ikah. "Analisis Terhadap Pemikiran Zakiah Darajat Tentang Didaktik dan Metodik Pendidikan Islam”. Skripsi: IAIN Curup. 2018.

Istiarsono, Zen. “Tantangan Pendidikan Dalam Era Globalisasi: Kajian Teoritik”, Jurnal Intelegensia, Vol. 2, No. 1, (2016): 3.

Jabiri, M. Abid, et.al. Pemikiran Islam Kontemporer. Yogyakarta: Jendela. 2003.

Karwadi. "Tujuan Pendidikan Islam Dalam Pemikiran Hasan Langgulung", Jurnal PAI, Vol. 4, No. 2 (2009): 137-158.

Kasijan. Psikologi Pendidikan. Surabaya: Bina Ilmu. 1984.

Langgulung, Hasan . Teori-teori Kesehatan Mental. Jakarta: Pustaka Al Husna. 1986. . Asas-asas Pendidikan Islam. Jakarta: Al Husna Zikra. 2000.

. Manusia dan Pendidikan, Suatu Analisa Psikologi, Filsafat dan Pendidikan. Jakarta: Pustaka Al Husna. 2004.

Madjid, Nurcholish. Bilik-Bilik Pesantren: Sebuah Potret Perjalanan. Jakarta: Paramadina, 1997.

Mawangir, Muhamad. "Zakiah Darajat dan Pemikirannya tentang Peran Pendidikan Islam dan Kesehatan Mental," Jurnal Imu Agama, Vol. 16, No. 2 (2015): 53-56.

Mochtar, Affandi. Membedah Diskursus Pendidikan Islam. Ciputat: Kalimah. 2001. 
Mubarak. "Urgensi Psikologi Islam Dalam Pendidikan Islam”. Jurnal Studia Insania, Vol. 5. No. 2 (2017): 215.

Muhaimin. Pemikiran dan Aktualisasi Pengembangan Pendidikan Islam. Jakarta: Rajawali Press. 2011.

Muhaminin dan Abdul Mujib. Pemikiran Pendidikan Islam. Bandung: Tigenda Karya. 1993.

Musfah, Jejen. Membumikan Pendidikan Holistik. Jakarta: Kencana. 2012.

Nata, Abuddin. Sosiologi Pendidikan Islam. Jakarta: Rajawali Pers. 2014.

Nizar, Samsul. Dasar-dasar Pemikiran Pendidikan Islam. Padang: IAIN Imam Bonjol Press. 2000.

Prasetyo,M.AM. "Peranan Perilaku Organisasi dan Manajemen Strategi dalam Meningkatkan Produktivitas Output Pendidikan", Jurnal Idarah, Vol. 1, No. 8 (2018): 80-101.

Primarni, Amie dan Khairunnas. Pendidikan Holistik: Format Baru Pendidikan Islam Membentuk Karakter Paripurna. Jakarta: AMP Press. 2016.

Purnama, Indra. et.al. Potret Pendidikan Indonesia. Bandung: Mujahid Press. 2020.

Rif'an, A. “Quality dalam Perspektif Pendidikan Islam”, Jurnal Piwulang, Vol. 1, No. 1 (2018): 19-32.

Rifa'i, Syukri. "Strategi Pendidikan Islam dalam Meningkatkan Kualitas Sumber Daya Manusia". Skripsi: Fakultas Ilmu Tarbiyah dan Keguruan UIN Syarif Hidayatullah Jakarta. 2006.

Roqib, Moh. Ilmu Pendidikan Islam; Pengembangan Pendidikan Integratif di Sekolah, Keluarga dan Masyarakat. Yogyakarta: LKiS. 2009.

Rusdiana, A. "Integrasi Pendidikaan Agama Islam Dengan Sains dan Teknologi”, Jurnal Istek, Vol. 8, No. 2 (Agustus 2014): 123-143.

Sairin, Sjafri. Perubahan Sosial Masyarakat Indonesia: Prespektif Antropologi. Yogyakarta: Pustaka Pelajar. 2002.

Sarjono. "Nilai-nilai Dasar Pendidikan Islam", Jurnal Pendidikan Agama Islam, Vol. 2, No. 2 (2005): 138.

Shihab, M Quraisy. Wawasan al Qur'an: Tafsir Maudhu'I atas Pelbagai Persoalan Umat. Bandung: Mizan. 1996.

SM, Ismail, et.al, Dinamika Pesantren dan Madrasah. Yogyakarta: Pustaka Pelajar. 2002.

Steenbrink, Karel A. Pesantren, Madrasah, Sekolah: Pendidikan Islam dalam Kurun Modern. Jakarta: LP3ES, 1994.

Sudja'i, Ahmad (ed). Pemikiran Pendidikan Islam Kajian Tokoh Klasik dan Kontemporer. Yogjakarta: Pustaka Pelajar, 1999.

Susanto, A. Pemikiran Pendidikan Islam. Jakarta: Amzah. 2010.

Suyanto dan MS. Abbas. Wajah Dinamika Pendidikan Anak Bangsa. Yogyakarta: Adicita Karya Nusa. 2004. 
Syah, Muhibbin. Psikologi-Psikologi Pendidikan dengan Pendekatan Baru. Bandung: Remaja Rosdakarya, 2003.

Tafsir, Ahmad. Epistemologi Untuk Ilmu Pendidikan Islam. Bandung: Fak. Tarbiyah IAIN Gunung Djati. 1995.

Taufiq. "Pemikiran Pendidikan Islam Menurut Hasan Langgulung Dalam Perspektif Psikologi” Makalah Publikasi: Universitas Muhammadiyah Surakarta, 2014.

Ulwiyah, Nur. "Landasan Psikologi dan Aktualisasinya dalam Pendidikan Islam”. Religi: Jurnal Studi Islam. Vol. 6. No. 1 (2015): 76-99.

Yusuf, Syamsul. Kesehatan Mental: Perspektif Psikologis dan Agama. Bandung: PT Remaja Rosdakarya. 2018.

Zuchdi, Darmiyati. Humanisasi Pendidikan. Jakarta: PT Bumi Aksara. 2009. 